\title{
UPAYA MENINGKATKAN KEMAMPUAN PEMECAHAN MASALAH MATEMATIK SISWA MELALUI PENDEKATAN OPEN-ENDED
}

\author{
Indrie Noor Aini, M.Pd. \\ Universitas Singaperbangsa Karawang, Karawang; indrienooraini@gmail.com
}

\begin{abstract}
Abstrak
Pemecahan masalah merupakan suatu proses untuk mengatasi kesulitan yang dihadapi untuk mencapai suatu tujuan yang hendak dicapai. Untuk meningkatkan kemampuan pemecahan masalah matematika, salah satunya dengan pembelajaran menggunakan pendekatan Open-Ended. Pendekatan Open-Ended membahas dan memecahkan masalah dengan asumsi bahwa proses lebih utama daripada hasil. Pendekatan Open-Ended memberi keleluasaan pada siswa untuk mengemukakan jawaban. Penelitian ini bertujuan untuk meningkatkan kemampuan pemecahan masalah matematik siswa setelah menggunakan pendekatan Open-Ended. Untuk mengarah kepada tujuan tersebut, maka penelitian ini mengkaji kemampuan pemecahan masalah matematik siswa dalam pembelajaran matematika dengan pendekatan Open-Ended pada setiap siklus. Penelitian ini dilaksanakan dengan metode penelitian tindakan kelas dengan subjek penelitian siswa kelas IX Program Khusus MTs. Darussalam Ciamis dengan jumlah siswa sebanyak 22 siswa. Instrumen yang digunakan dalam penelitian ini adalah lembar observasi yang meliputi aktivitas guru dan siswa; tes formatif dan posttest untuk mengukur kemampuan pemecahan masalah matematik siswa. Hasil penelitian ini adalah kemampuan pemecahan masalah matematik siswa pada setiap siklus adalah baik, serta ketuntasan belajar klasikal berkategori baik.
\end{abstract}

Kata Kunci : kemampuan pemecahan masalah, pedekatan Open-Ended.

\section{Abstract}

Problem solving is a process to fix the difficulties encountered the achievement a goal to be achieved. To improve the ability of problem solving mathematical, one of them by learning to use the Open-Ended approach. OpenEnded approach to discuss and solve problems with the assumption that the process is more important than the result. Open-Ended approach gives flexibility to the student to put the answer. This study aims to improve students' mathematical problem solving ability after using the Open-Ended approach. To lead to these objectives, this study examines the mathematical problem solving ability of students in mathematics learning with the Open-Ended approach in every cycle. This 
research was conducted by the method of action research with research subjects students of class IX MTs Special Program. Darussalam Ciamis, the number of students as subject is 22 students. The instrument used in this study is the observation sheet that covers the activities of teachers and students; formative test and posttest to measure students' mathematical problem solving ability. The results of this study are mathematical problem solving ability of students in each cycle is good, as well as the completeness of classical study categorized either.

Keywords : problem-solving ability, Open-Ended approach.

\section{A. PENDAHULUAN}

Berbicara matematika tentunya tidak akan terlepas dari masalah dan pemecahannya. Kedua hal tersebut telah menjadi bagian dari matematika itu sendiri. Dalam prakteknya masalah dalam matematika tersebut dipresentasikan melalui soal-soal dengan taraf kesulitan tertentu yang menuntut adanya pemecahan.

Pemecahan masalah merupakan kegiatan yang sangat penting dalam pembelajaran matematika. Pentingnya kemampuan pemecahan masalah matematika dimiliki oleh siswa dikemukakan oleh Branca (Jihad, 2006: 1) :

(1) kemampuan menyelesaikan merupakan tujuan umum pengajaran matematika, bahkan sebagai jantungnya matematika; (2) penyelesaian masalah meliputi metoda, prosedur dan strategi merupakan proses inti dan utama dalam kurikulum matematika; dan (3) penyelesaian matematika merupakan kemampuan dasar dalam belajar matematika.

Kemampuan pemecahan masalah merupakan salah satu fokus dan kemampuan yang harus ditingkatkan. Siswa dituntut memiliki kemampuan untuk menghubungkan elemen-elemen dalam belajar, seperti pengetahun, keterampilan dan pemahaman sehingga akhirnya dapat menyelesaikan masalah yang dihadapi dengan baik (Rokhmah, 2008: 2). Senada dengan yang dikatakan Shimada (Suherman dkk, 2003: 124) bahwa "dalam pembelajaran matematika rangkaian pengetahuan, keterampilan, konsep, prinsip atau aturan yang diberikan kepada siswa biasanya melalui langkah-langkah". Tentu saja rangkaian ini sebagai rangkaian terintegrasi dengan kemampuan dan sikap dari setiap siswa, sehingga didalam pikiran mereka akan terjadi pengorganisasian intelektual yang optimal.

$$
\text { Model pembelajaran }
$$

matematika yang diterapkan saat ini oleh sebagian besar guru adalah model yang lebih mengutamakan hapalan, keterampilan berhitung, hasil akhir dan terpusat pada guru. Seringnya siswa dijejali dengan berbagai rumus matematika, menyebabkan pelajaran matematika cenderung dijadikan hapalan tanpa memahami apa yang sedang dihapal, sehingga siswa akan mempunyai kecenderungan verbalistik, seharusnya siswa didorong untuk 
mengkonstruksi kemampuan didalam pikiran sendiri. Hal ini senada dengan yang dikatakan Ruseffendi (1991: 156) bahwa matematika merupakan pengetahuan yang memerlukan penalaran bukan untuk dihapal. Akibatnya ketika siswa diberikan masalah untuk melihat pemahaman mereka mengenai materi matematika, siswa selalu kesulitan dalam menyelesaikan soal dengan bentuk yang hampir sama. Hal itu menandakan bahwa mereka belum dapat menangkap kerangka berpikirnya, melainkan menghapal penyelesaiannya.

Sementara itu pemberian masalah matematika masih sering menggunakan cara tradisional yang disajikan dalam bentuk tertutup, yaitu hanya memiliki satu alternatif jawaban yang benar. Sehingga siswa terpaku hanya pada satu cara untuk menemukan satu jawaban yang benar. Cara seperti ini kurang mampu melihat kemampuan siswa dalam proses penyelesaian masalah, karena hanya berorientasi pada hasil akhir.

Dalam proses pembelajaran, guru dapat mengajukan pertanyaanpertanyaan yang memancing siswa berpikir dalam memecahkan suatu permasalahan. Guru dapat merancang proses pembelajaran dengan memungkinkan siswa mencari jawaban atau metode lebih dari satu atas persolan yang diajukan. Pola pembelajaran seperti itu, dalam pembelajaran matematika dikenal dengan nama pendekatan Open-Ended.
Pembelajaran dengan pendekatan Open-Ended adalah pembelajaran yang membangun kegiatan interaktif antara matematika dan siswa sehingga mengundang siswa untuk menjawab permasalahan melalui berbagai strategi (Suherman, 2003: 124). Pembelajaran dengan menggunakan pendekatan Open-Ended memberikan keleluasaan kepada setiap siswa untuk mengembangkan ide berpikirnya dalam memecahkan permasalahan matematika. Sehingga siswa bisa mengeksplor kemampuan pemecaan masalah yang mereka miliki.

Berdasarkan latar belakang masalah yang telah dikemukakan sebelumnya, rumusan masalah dalam penelitian ini adalah bagaimana kemampuan pemecahan masalah matematis setiap siswa setelah mengikuti seluruh siklus melalui penerapan pendekatan Open-Ended?

Mengacu pada masalah yang telah dirumuskan, maka tujuan dari penelitan ini adalah menelaah kemampuan pemecahan masalah matematis siswa dengan menggunakan pendekatan Open-Ended sehingga dapat diketahui indikator pemecahan masalah mana yang sudah dikuasai dan belum dikuasai siswa setelah dilaksanakan seluruh siklus.

Penelitian ini diharapkan dapat memberikan manfaat bagi berbagai kalangan. Terutama bagi pengajar matematika di MTs. / SMP. Apabila seluruh siklus sudah dilaksanakan dan ditelaah dapat diketahui siswa sudah 
menguasai materi seluruh siklus atau belum dan materi mana yang sekiranya belum dikuasai di seluruh siklus tersebut, sehingga guru dapat memperbaiki pembelajaran pada materi lain untuk pembelajaran berikutnya.

\section{B. KAJIAN TEORI}

Pemecahan masalah merupakan bagian dari kurikulum matematika yang sangat penting (Suherman, 2003: 89), karena dalam proses pembelajaran maupun penyelesaian, siswa dimungkinkan memperoleh pengalaman menggunakan pengetahuan serta keterampilan yang sudah dimiliki untuk diterapkan pada pemecahan masalah yang bersifat tidak rutin.

Menurut Branca (dalam Hendriana, 2002: 12) bahwa kemampuan pemecahan masalah merupakan tujuan umum dalam pembelajaran matematika, artinya kemampuan pemecahan masalah merupakan kemampuan dasar dalam belajar matematika.

\section{Sudjimat (dalam Sukasno,} 2002: 18) menyatakan bahwa belajar pemecahan masalah pada hakekatnya adalah belajar berpikir (learning to think) atau belajar bernalar (learning to reason), yaitu berpikir atau bernalar mengaplikasikan pengetahuanpengetahuan yang telah diperoleh sebelumnya untuk memecahkan masalah-masalah baru. Oleh karena itu pembelajaran matematika yang bernuansa pemecahan masalah harus dirancang sedemikian rupa sehingga mampu merangsang siswa untuk berpikir dan mendorong siswa menggunakan pikirannya secara sadar untuk memecahkan masalah matematika tersebut.

Langkah-langkah atau tahapan menyelesaikan masalah matematika yang merupakan indikator dari pemecahan masalah menurut Polya (Susilawati, 2007: 128) ada empat yaitu: (1) memahami masalah, yaitu memahami apa yang ditanyakan dan diketahui dalam permasalahan, (2) merencanakan penyelesaian, yaitu merumuskan masalah serta menyusun ulang masalah, (3) melakukan perhitungan, yaitu melakukan perhitungan untuk menyelesaikan masalah sesuai dengan langkah sebelumnya, (4) memeriksa kembali proses dan hasil, yaitu mengecek langkah-langkah yang sudah dilakukan.

Dalam penelitian ini, indikator atau langkah-langkah penyelesaian masalah yang digunakan adalah langkah-langkah pemecahan masalah menurut Polya. Polya mengklasifikasikan penerapan pemecahan masalah matematika, yaitu penyelesaian soal-soal non-rutin, penerapan matematika pada masalah dunia nyata dan menciptakan serta menguji konjektur.

Pendekatan

Open-Ended membahas dan memecahkan masalah, dengan asumsi bahwa proses lebih utama daripada hasil, yang menekankan pada upaya pemecahan masalah, dengan merumuskan 
permasalahan terlebih dahulu. Dalam pendekatan Open-Ended terdapat keragaman dalam penyelesaian ataupun metode penyelesaiannya. Pendekatan Open-Ended memberi keleluasaan pada siswa untuk mengemukakan jawaban, serta memberikan pengalaman bagi siswa untuk menemukan sesuatu yang baru.

Pendekatan Open-Ended adalah pendekatan pembelajaran yang menyajikan suatu permasalahan yang memiliki metode atau penyelesaian yang benar lebih dari satu juga memberikan kesempatan kepada siswa untuk memperoleh pengetahuan atau pengalaman menemukan, menggali dan memecahkan masalah dengan beberapa teknik". Sehingga dalam penyelesaian masalah, kebenaran penyelesaian tidak hanya tergantung pada hasil akhir tapi juga tergantung pada proses yang dilalui dalam menemukan penyelesaian tersebut. Karena suatu soal dikatakan soal pemecahan masalah apabila siswa memiliki kemampuan dan pengetahuan untuk menyelesaikannya, tetapi pada saat memperoleh soal itu siswa belum tahu cara menyelesaikannya. Sedangkan masalah yang baik adalah masalah yang dapat dipecahkan lebih dari satu cara dengan melihat kemampuan siswa dan menimbulkan minat siswa untuk memecahkannya.

\section{Pendekatan Open-Ended} merupakan salah satu pendekatan yang menghargai keragaman berpikir yang mungkin timbul selama proses pencarian jawaban. Selain mendorong siswa untuk bernalar dan menampilkan bukti untuk pemikirannya, soal-soal Open-Ended ini membuat siswa jadi tertarik untuk mengkomunikasikan gagasannya serta menemukan hubungan antara matematika dengan kehidupan nyata.

\section{METODE PENELITIAN}

\section{Metode Penelitian}

Metode Penelitian yang digunakan adalah metode Classroom Action Research (CAR) atau yang lebih dikenal dengan Penelitian Tindakan Kelas (PTK). Penelitian Tindakan Kelas (PTK) merupakan ragam penelitian pembelajaran berkonteks kelas yang dilaksanakan oleh guru untuk memecahkan masalah-masalah pembelajaran yang dihadapi guru, memperbaiki kualitas dan hasil pembelajaran dan mencobakan hal-hal baru pembelajaran demi peningkatan kualitas dan hasil pembelajaran.

Penelitian Tindakan Kelas melibatkan interaksi, partisipasi dan kolaborasi antara peneliti (guru) dengan siswa. Adapun langkah-langkah yang akan dilakukan dalam penelitian ini berbentuk siklus dengan berpedoman pada model yang diadaptasi dari Sudikin dkk (Sofyan, 2006: 14) dimana setiap siklus terdiri dari empat komponen kegiatan pokok, yaitu: (a) Perencanaan (planning); (b) Tindakan (acting); (c) Pengamatan (observing); (d) Refleksi (reflecting). Pada pelaksanaannya, keempat komponen kegiatan pokok itu berlangsung secara terus-menerus.

\section{Tempat dan Subjek Penelitian}


Sekolah yang dijadikan lokasi penelitian tindakan kelas adalah MTs. Darussalam Ciamis. Adapun yang menjadi subjek penelitian adalah siswa kelas IX Program Khusus MTs. Darussalam Ciamis dengan jumlah siswa sebanyak 22 orang, yakni 18 siswa perempuan dan 4 siswa laki-laki.

Pemilihan ini didasarkan pada hasil studi pendahuluan yang dilakukan peneliti menunjukkan bahwa kemampuan pemecahan masalah matematik siswa kelas IX MTs. Darussalam Ciamis heterogen dan masih terdapat sebagian siswa yang belum mampu memahami masalah, merencanakan penyelesaian soal dan belum mampu memeriksa kembali hasil jawaban.

\section{Prosedur Penelitian}

Prosedur dalam penelitian ini meliputi empat langkah, yaitu :

Perencanaan

Setelah melaksanakan studi pendahuluan dan ternyata memungkinkan untuk melakukan penelitian ini, maka tahap perencanaan pada penelitian ini adalah menyusun jadwal penelitian, menyiapkan RPP (Rencana Pelaksanaan Pembelajaran) untuk setiap siklus, menyiapkan instrumen pembelajaran untuk setiap siklus, yakni lembar observasi siswa dan guru, tes (tes formatif dan tes akhir) dan skala sikap, serta menyiapkan alat dan bahan yang dibutuhkan dalam penelitian.

Pelaksanaan tindakan dan observasi. Pada penelitian tindakan kelas ini dilaksanakan pembelajaran matematika dengan menggunakan pendekatan Open-Ended untuk masingmasing siklus sebanyak satu pertemuan, masing-masing dua jam pelajaran. Selama proses pembelajaran berlangsung dilaksanakan observasi oleh observer untuk mengobservasi aktivitas siswa dan aktivitas guru. Pada akhir siklus, siswa diberikan tes formatif untuk melihat tingkat penguasaan materi hasil pembelajaran.

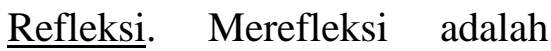
proses berfikir untuk melihat aktivitas yang telah dilaksanakan serta menentukan solusinya berdasarkan hasil observasi dan temuan di kelas pada saat pembelajaran berlangsung. Jika terdapat masalah pada proses refleksi, maka disusun perbaikan khususnya pada perangkat pembelajaran. Setelah selesai melaksanakan pembelajaran maka dilakukan refleksi untuk mengetahui kekurangan dan kelebihan dari apa yang telah dilakukan serta melihat kembali aktivitas yang sudah dilakukan berdasarkan hasil observasi dan temuan di kelas pada saat pembelajaran berlangsung, menganalisis data hasil evaluasi dan mencari solusi serta menyusun perbaikan khususnya pada perangkat pembelajaran untuk siklus selanjutnya berdasarkan hasil analisis kegiatan.

Setelah satu siklus selesai dilaksanakan, maka dapat dilanjutkan ke siklus kedua dengan memperhatikan kekurangan-kekurangan yang terjadi pada siklus pertama yang harus 
diperbaiki pada siklus kedua, dan seterusnya sampai selesai dengan langkah-langkah yang sama dengan siklus pertama. Setelah selesai seluruh siklus, dilaksanakan tes akhir yang mencakup seluruh materi dari siklus pertama sampai siklus akhir.

\section{Intrumen dan Teknik Pengumpulan Data}

Instrumen yang digunakan untuk mengumpulkan data dalam penelitian ini sesuai dengan masalah yang telah dirumuskan, yakni :

Tes

Tes ini untuk memperoleh nilai dari kemampuan pemecahan masalah matematika pada pokok bahasan Luas Permukaan dan Volume tabung dan Kerucut dari siswa kelas IX Program Khusus MTs. Darussalam Ciamis. Tes yang digunakan dalam penelitian ini adalah tes kemampuan pemecahan masalah matematik siswa, berupa tes uraian dengan alasan bahwa dengan tes uraian dapat diketahui proses berpikir, langkah-langkah pengerjaan serta ketelitian siswa. Tes ini meliputi tes tiap siklus (tes formatif) dan tes akhir (posttest) yang berorientasi untuk meningkatkan kemampuan pemecahan masalah matematik siswa.

Indikator kemampuan pemecahan masalah matematik yang digunakan dalam penelitian ini adalah (1) Memahami masalah; Merencanakan penyelesaian; Melakukan perhitungan; dan memeriksa kembali proses.
Klasifikasi kualitas pemecahan masalah matematik siswa adalah sebagai berikut:

Tabel 1

Klasifikasi Kemampuan

Pemecahan Masalah Matematik

\begin{tabular}{cc}
\hline $\begin{array}{c}\text { Persentase Kemampuan } \\
\text { Pemecahan Masalah } \\
\text { Matematik Siswa }\end{array}$ & Klasifikasi \\
\hline $90 \leq \mathrm{A} \leq 100$ & Sangat Tinggi \\
$75 \leq \mathrm{B}<90$ & Tinggi \\
$55 \leq \mathrm{C}<75$ & Cukup \\
$40 \leq \mathrm{D}<55$ & Rendah \\
$0 \leq \mathrm{E}<40$ & Sangat Rendah \\
\hline
\end{tabular}

Non-tes (Observasi)

Observasi yang digunakan dalam penelitian ini adalah observasi langsung dengan tujuan untuk memperoleh gambaran langsung tentang proses pembelajaran dengan pendekatan Open-Ended dan untuk mengamati aktivitas siswa dan aktivitas guru selama proses pembelajaran dengan pendekatan Open-Ended. Kemudian data yang diperoleh diolah sebagai data kualitataif. Sedangkan untuk alat bantu yang digunakan adalah lembar observasi aktivitas belajar siswa dan lembar aktivitas guru.

Secara garis besar teknik pengumpulan data dalam penelitian ini dapat dilihat pada Tabel 2 berikut:

Tabel 2

\begin{tabular}{ccccc}
\hline & Sumber & Aspek & Instrumen & Teknik \\
No & Data & & yang & Pengumpulan \\
& & & Digunakan & Data \\
\hline 1 & Siswa & Kemampuan & Perangkat & Tes evaluasi \\
\hline
\end{tabular}




\begin{tabular}{lllll}
\hline & & $\begin{array}{l}\text { pemecahan } \\
\text { masalah } \\
\text { matematika }\end{array}$ & $\begin{array}{c}\text { tes } \\
\text { kemampuan } \\
\text { pemecahan } \\
\text { masalah }\end{array}$ & $\begin{array}{l}\text { pada akhir } \\
\text { setiap siklus } \\
\text { dan post test }\end{array}$ \\
\hline 2 & Guru & Gambaran & Lembar & Observasi \\
& dan & proses & Observasi & \\
& siswa & pembelajaran & aktivitas & \\
& & dengan & siswa dan & \\
& & pendekatan & aktivitas & \\
& Open-Ended & guru & \\
\hline
\end{tabular}

\section{Teknik Analisis Data}

Setelah data yang diperlukan terkumpul, selanjutnya dilakukan analisis data. Hasil penilaian kemampuan siswa pada tes formatif dan tes akhir akan dideskripsikan ke dalam gambar dan diklasifikasikan sesuai dengan standar kriteria dengan mengubah terlebih dahulu skor penilaian kemampuan siswa dan ratarata siswa ke dalam bentuk persen yang rumusnya seperti telah dipaparkan pada pembahasan instrumen tes.

Sedangkan untuk mengetahui tingkat ketuntasan belajar setelah seluruh siklus selesai, maka analisis datanya adalah dengan menghitung persentase daya serap dan ketuntasan belajar setiap tes formatif. Ketuntasan belajar yang dijadikan pijakan dalam penelitian ini berdasarkan petunjuk pengolahan penilaian Depdikbud (Jihad, 2006: 66), bahwa : "seseorang disebut telah tuntas belajar, jika sekurang-kurangnya dapat mengerjakan soal dengan benar sebanyak $65 \%$. Secara proporsional, hasil belajar suatu rombongan belajar dikatakan baik apabila sekurangkuranganya $85 \%$ siswa telah tuntas belajar. Apabila siswa yang tuntas hanya mencapai $75 \%$, maka hasil belajarnya dikatakan cukup. Hasil belajar dikatakan kurang apabila prosentase anggota yang tuntas kurang dari 60\%".

Ketuntasan perorangan

$$
\begin{aligned}
& = \\
& \frac{\text { jumlah jawaban yang benar }}{\text { jumlah skormaksimalideal }} \times 100 \%
\end{aligned}
$$

Ketuntasan klasikal $=$

$$
\frac{\sum s \geq 65 \%}{n} \times 100 \%
$$

Daya serap klasikal

$$
=
$$

$\frac{\text { jumlah skortotal siswatuntas belajar }}{\text { jumlah siswa } \times \text { skormaksimalideal }}$

Keterangan:

$$
\sum s \geq 65 \%=\text { Jumlah siswa }
$$

yang memperoleh daya serap lebih dari atau sama dengan $65 \%$

$$
n=\text { Banyak siswa }
$$

\section{HASIL PENELITIAN DAN PEMBAHASAN}

Berdasarkan analisis hasil tes formatif dan tes akhir, diperoleh informasi bahwa kemampuan pemecahan masalah matematik siswa kelas IX Program Khusus MTs. Darussalam Ciamis pada pokok bahasan Luas Permukaan dan Volume Tabung dan Kerucut dengan pendekatan Open-Ended dari siklus I sampai akhir pembelajaran mengalami perkembangan naik-turun seperti tampak pada Gambar 1. Pada siklus I persentase rata-rata kemampuan pemecahan masalah matematik siswa adalah $71,67 \%$ dengan klasifikasi baik. Pada siklus II mengalami kenaikan 
menjadi $77,95 \%$ dengan klasifikasi cukup. Beberapa penyebabnya adalah siswa mulai terbiasa dengan soal pemecahan masalah bentuk OpenEnded, sehingga siswa sudah bisa menyelesaikannya walaupun belum sempurna.

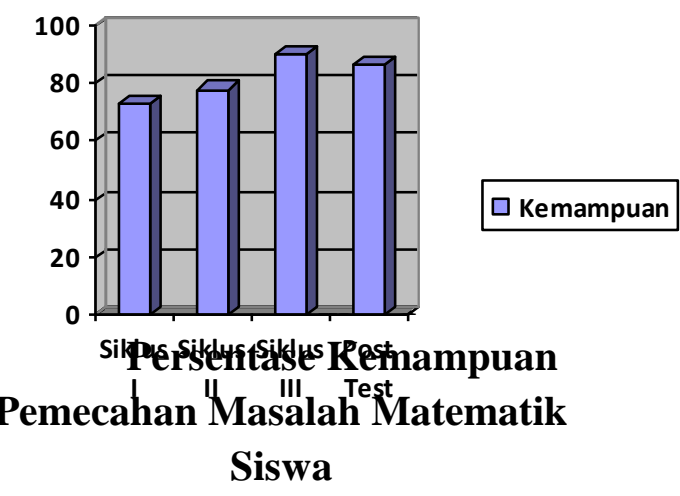

Pada siklus III, persentase ratarata kemampuan pemecahan masalah matematik siswa mengalami kenaikan juga yaitu menjadi $90 \%$ dengan klasifikasi baik. Kenaikan ini dipicu oleh adanya upaya perbaikan kegiatan pembelajaran. Sehingga siswa mulai terbiasa dan terkondisikan dengan pembelajaran pendekatan Open-Ended dan terbiasa menghadapi soal-soal pemecahan masalah pada pokok bahasan Luas Permukaan dan Volume Tabung dan Kerucut. Sedangkan pada hasil tes formatif, mengalami penurunan menjadi $86,56 \%$ dengan klasifikasi baik. Hal ini diantaranya disebabkan oleh kurangnya kesiapan siswa dalam menghadapi tes formatif karena jumlah soal pada tes akhir lebih banyak, sehingga siswa merasa waktu yang diberikan tidak cukup.

Pada dasarnya mayoritas siswa sudah dapat memahami masalah, dapat merencanakan penyelesaian, dapat menyelesaikan masalah atau melakukan perhitungan sesuai dengan prosedur yang ada serta dapat memeriksa kembali. Namun, pada langkah keempat yaitu memeriksa kembali, hampir seluruh siswa hanya memeriksa hasil saja, tidak dengan prosesnya.

Dengan demikian, secara umum dapat dikatakan bahwa kemampuan pemecahan masalah matematik siswa kelas IX Program Khusus MTs. Darussalam Ciamis setelah diterapkan pembelajaran dengan pendekatan Open-Ended pada pokok bahasan Luas Permukaan dan Volume Tabung dan Kerucut adalah termasuk kategori baik. Sama halnya dengan ketuntasan belajar klasikal dan daya serap klasikal siswa kelas IX Program Khusus MTs. Darussalam Ciamis setelah diterapkan pembelajaran dengan pendekatan Open-Ended pada pokok bahasan Luas Permukaan dan Volume tabung dan Kerucut mengalami perkembangan seperti terlihat pada Tabel berikut:

Tabel 3

Ketuntasan Belajar Siswa

\begin{tabular}{cccc}
\hline Tes & $\begin{array}{c}\text { Ketuntasan } \\
\text { Belajar } \\
(\boldsymbol{\%})\end{array}$ & $\begin{array}{c}\text { Daya } \\
\text { Serap } \\
(\boldsymbol{\%})\end{array}$ & $\begin{array}{c}\text { Kriteria } \\
\text { Ketuntasan }\end{array}$ \\
\hline Siklus I & 86,36 & 71,67 & Baik \\
\hline $\begin{array}{c}\text { Siklus } \\
\text { II }\end{array}$ & 86,36 & 77,92 & Baik \\
\hline $\begin{array}{c}\text { Siklus } \\
\text { III }\end{array}$ & 95,45 & 90 & Sangat Baik \\
\hline $\begin{array}{c}\text { Tes } \\
\text { formatif }\end{array}$ & 100 & 86,65 & Sangat Baik \\
\hline
\end{tabular}


Berdasarkan data hasil tes evaluasi siswa pada tes akhir diperoleh informasi sebagai berikut :

Kemampuan

pemecahan

masalah matematik siswa pada tes akhir. Banyaknya siswa yang memiliki kemampuan pemecahan masalah matematik sesuai dengan kriteria penilaian dapat dilihat pada Tabel 3 Pernyataan dalam Tabel tersebut diperoleh dari hasil analisis jawaban siswa pada tes akhir yang dilaksanakan setelah seluruh rangkaian pembelajaran siklus selesai.

Tabel 4

Kemampuan Pemecahan

\section{Masalah Matematik Siswa Setelah} Seluruh Siklus

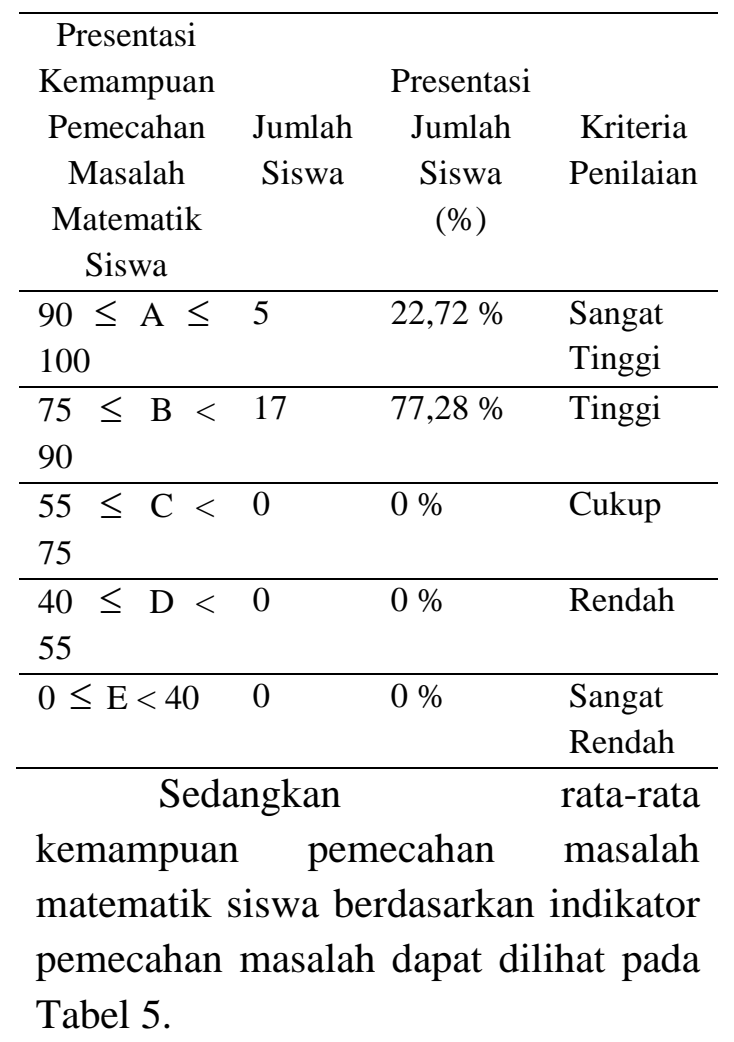

Tabel 5

Rata-rata Kemampuan

Pemecahan Masalah Matematik

\begin{tabular}{ll}
\hline Indikator & Rata-rata \\
\hline Memahami Masalah & 1,9 \\
\hline Merencanakan Penyelesaian & 3,2 \\
\hline Melaksanakan Penyelesaian & 3,2 \\
\hline Memeriksa Kembali Jawaban & 1,8 \\
\hline Informasi Baru & 2 \\
\hline \multicolumn{1}{c}{ Dari Tabel 5} & diperoleh
\end{tabular}

informasi bahwa kemampuan memahami masalah siswa dalam tes Akhir didapat rata-rata rata-rata 1,91. Dalam kategori kemampuan ini mengalami perubahan yang signifikan. Untuk kemampuan merencanakan masalah didapat ratarata 3,2. Hal ini disebabkan siswa mengalami kesulitan dengan jenis soal yang diberikan. Untuk kemampuan melaksanakan penyelesaian didapat rata-rata 3,2. Hal ini disebabkan karena siswa sudah terbiasa dalam menyelesaikan perhitungan dengan baik.

Kemampuan memeriksa kembali jawaban didapat rata-rata 1,8 dan kemampuan memperoleh informasi baru di dapat rata-rata 2. Oleh karena itu, siswa terlihat antusia dalam mengerjakan soal pemecahan masalah bentuk Open Ended yang disajikan. Angka dari nilai rata-rata tersebut diperoleh dari rata-rata masing-masing indikator dibagi dengan jumlah soal.

Banyaknya siswa yang tuntas mengikuti pembelajaran pada tes akhir sesuai dengan kriteria penilaian yang dapat dilihat pada Tabel 6 . 
Tabel 6

Ketuntasan Individu Siswa

Setelah Seluruh Siklus

\begin{tabular}{ll}
\hline Daya Serap Siswa & Jumlah Siswa \\
\hline$\geq 65 \%$ & 22 orang \\
\hline$<65 \%$ & - \\
\hline
\end{tabular}

Dari Tabel 6 diperoleh informasi siswa yang tuntas sebanyak 22 orang siswa dari 22 orang siswa yang mengikuti tes akhir sehingga tidak ada siswa yang tidak tuntas, artinya ketuntasan belajar tes akhir sebesar $100 \%$. Bisa dikatakan bahwa proses pembelajaran dengan pendekatan Open-Ended berjalan dengan lancar walaupun ada sedikit kekurangan.

\section{E. SIMPULAN DAN SARAN}

Berdasarkan hasil penelitian mengenai penggunaan pendekatan Open-Ended untuk meningkatkan kemampuan pemecahan masalah matematik siswa kelas IX Program Khusus MTs. Darussalam Ciamis, diperoleh kesimpulan bahwa kemampuan pemecahan masalah matematik siswa kelas IX Program Khusus MTs. Darussalam Ciamis pada pokok bahasan Luas Permukaan dan Volume Tabung dan Kerucut setelah seluruh siklus atau setelah diterapkannya pendekatan Open-Ended menunjukkan kategori baik dengan rata-rata kemampuan pemecahan masalah matematik siswa sebesar $86,56 \%$ dan ketuntasan belajar klasikal siswa berkategori baik dengan persentase mencapai $100 \%$. Sehingga pembelajaran matematika melalui pendekatan Open-Ended dapat meningkatkan kemampuan pemecahan masalah matematik siswa.

$$
\text { Pembelajaran matematika }
$$

melalui pendekatan Open-Ended bertujuan untuk membuat siswa berpikir kreatif dan berpikir matematika secara simultan. Oleh karena itu hal yang perlu diperhatikan adalah kebebasan siswa untuk berpikir dalam membuat progress pemecahan sesuai dengan kemampuan, sikap, dan minatnya sehingga pada akhirnya akan membentuk intelegensi matematika siswa.

Berdasarkan hasil penelitian
bahwa dengan diterapkannya pendekatan Open-Ended menghasilkan kemampuan pemecahan masalah matematik siswa berkategori cukup. Sehingga pembelajaran matematika dengan pendekatan Open-Ended ini dapat dijadikan sebagai alternatif yang dapat diterapkan sekali-kali sebagai selingan dalam pembelajaran matematika oleh guru disekolah.

\section{DAFTAR PUSTAKA}

Arikunto, Suharsimi. 2010. DasarDasar Evaluasi Pendidikan. PT Bumi Aksara : Jakarta.

Dahar, Ratna Wilis. 1996. Teori Teori Belajar. Erlangga : Jakarta.

Fadillah. 2008. Jurnal Pendidikan dan Budaya. http://educare.e-

fkipunla.net Generated: 19 October, 2008

Afriana, Roni. 2006. Pengaruh Pembelajaran Matematika dengan Pendekatan Open-Ended terhadap Kemampuan Pengajuan dan Pemecahan Masalah. Skripsi UIN 
Sunan Gunung Djati Bandung.

Tidak diterbitkan.

Jupri, Al. 2008. Open-Ended Problems

dalam

Matematika.

http://mathematicse.wordpress.co

m/2007/12/25/open-ended-

problems-dalam-matematika

Nasution. 2008. Berbagai Pendekatan

dalam Proses Belajar dan

Mengajar. Bumi Aksara: Jakarta.

Rokhmah. 2008. Peningkatan

Kemampuan Pemecahan Masalah

Matematika Siswa Melalui

Penerapan Pedekatan Generative

Learning. Skripsi UIN Sunan

Gunung Djati Bandung. Tidak diterbitkan.

Ruseffendi, E.T. 1998. Pengantar kepada Membantu Guru Mengembangkan Kompetensinya dalam Pengajaran Matematika untuk Meningkatkan CBSA. Tarsito : Bandung.

Ruseffendi, E.T. 1991. Penilaian Pendidikan Dan Hasil Belajar Siswa Khususnya Dalam Pengajaran Matematika. Buku Diktat Kuliah dilingkungan UNINUS Bandung. Tidak diterbitkan.

Suherman, Erman dkk. 2003. Common Textbook (Edisi Revisi) Strategi Pembelajaran Matematika Kontemporer. Jurusan Pendidikan Matematika FPMIPA UPI Bandung : Bandung.

Susilawati, Wati. 2007. Belajar Dan Pembelajaran Matematika Mahasiswa Perguruan Tinggi Negeri dan Swasta -. Untuk Lingkungan Pribadi. 